\title{
Customer Perception Towards Green Banking
}

\author{
Dr.R.Ganesan, ${ }_{1}$ A.Bhuvaneswari ${ }^{2}$ \\ ${ }^{I}$ M.com, M.Phil, PhD, M.A.Corporate Secretary ship, M.Phil Corporate Secretary ship, NET.Associate \\ Professor Head Department of Commerce and Research ,D.G.Vaishnav College Arumbakkam Chennai, \\ TamilNadu, India \\ ${ }^{2}$ Research Scholar Department of Commerce, D.G.Vaishnav College , Arumbakkam, Chennai, TamilNadu,India
}

\begin{abstract}
Green banking refers to the banking business conducted in such areas and in such a manner that helps the overall reduction of external carbon emission and internal carbon footprint. To aid the reduction of external carbon emission and reduce global warming,, banks should finance green technology and pollution reducing projects. Change is the need of this hour although, banking is never considered a polluting industry, the present scale of banking operations have considerably increased the carbon footprint of banks due to their massive use of energy (e.g., lighting, air conditioning, electronic/electrical equipments, IT, etc), high paper wastage, lack of green buildings, etc. The study is conducted to evaluate the awareness of green banking, and level of green banking concept spread among the customers. The analysis made shows that ICICI bank and SBI bank are the two banks which provide major green banking services to its customers. Educational qualification has greater impact on usage of green banking facilities.
\end{abstract}

Keywords: Green banking, Awareness among customers, Online transactions, green projects

\section{Introduction}

“ Earth provides enough to satisfy every man's needs but not every man's greed"-Mahatma Gandhi Green Banking is an umbrella term referring to practices and guidelines that make banks sustainable in economic, environment, and social dimensions. It aims to make banking processes and the use of IT and physical infrastructure as efficient and effective as possible, with zero or minimal impact on the environment. Sustainable development and preservation of environment are now recognised globally as overriding imperatives to protect our planet from the ravages inflicted on it by mankind. Various global initiatives are underway to counter the ill effects of development that ween counter to day such as global warming and climate change. A common thread running across all these initiatives is the focus on reducing the demand for fossil fuels by implementing the3R'sviz.Reduce, Reuse and Recycle.

Banks and financial institutions can play a major and decisive role in these global efforts to make our planet a better place to live in. As providers of finance, banks can ensure that businesses adopt environmentfriendly practices. Incentives by way of offering cheaper funds for adopting green technologies will have a long term beneficial impact on the environment. As major implementers of technology, banks themselves can adopt green practices and thereby lead the way in this global initiative. Also, product innovation and leveraging on the use of technology enable banks and their customers today to reduce the usage of resources such as paper, thereby aiding in environmental protection. The case for sustainablegrowth is established beyond doubt.Reckless and unimaginative growthis endangering the planet and the adverse consequences are manifest in global warming, climate change, fickle weather, floods, droughts, pollution, high green house gas emissions, etc. While still there is no consensus among the countries on sharing the burden of ecological footprint, most of the countries have been taking aggressive measures to tackle global warming and climate change. Banks also contribute to ecological footprint directly and indirectly through investment/lending in their customer enterprises. As such they need to play a key role in optimizing /reducing the carbon footprint. It is said that what is not measured,is not managed.

\subsection{Problem Of Study:}

The attack of human beings on nature is the cause of environmental deterioration. This deterioration is leading to global warming and climate change. Climatic changes have been causing natural disasters like cyclones, floods, landslides, and droughts. Combined efforts of governments, corporate sector and individuals can help in minimizing these various forms of environmental deterioration. For this, governments have to come up with strong policies; corporate houses should follow environmental protection guidelines more strictly; and individuals have to be self-aware to protect the environment around them. Banks have been using lighting, air conditioning, electronic equipments, IT, high paper wastage in massive proportion. The resultant internal carbon footprint can be reduced through the use of renewable energy, automation and other measures. On the other hand, banks can reduce external carbon emission by financing projects and companies that are working for pollution reduction and adopting green technologies. 


\subsection{Objectives Of The Study}

1.2.1primary Objective

- To Study about the awareness of green banking among the customers.

\subsection{2secondary Objective}

- To analyse the problems faces by customers using green banking.

- To examine the effectiveness of green banking.

- To analyse the concept of green banking among different banks.

1.3research Design

Sources Of Data:

1.3.1 Primary Data: Primary data has been collected through structured questionnaire consisting of close ended multiple choice questions.

1.3.2 Secondary Data: The sources of secondary data are various research journals, books, research papers and banks websites.

1.3.3 Sampling Method: The sampling method adopted for the study is "Convenience sampling".

1.3.4 Sample Size: The sample size for the study is 100 to be collected from customers having accounts in various banks in Chennai

1.3.5 Data Collection Instrument: A structured questionnaire with close ended questions having totally 26 questions was used. The reason for using close ended questions was to get objective answers from the respondents.

1.3.6 Data Collection Method: A structured questionnaire with close ended questions was circulated and 67 responses were collected out of which 50were used to analyse ignoring the incomplete responses.

\subsubsection{Statistical Tools Used Or Applied:}

The following statistical tools were applied in order to analyse the data and interpret the same in order to draw conclusions with respect to the objectives set.

\# Chi Square analysis

\# Analysis of Variance - One way ANOVA (F Test)

\# Frequency tables

Chi-square analysis was used in order to identify the association between any two given variables. One way ANOVA was applied in order to find out the each variable and also to ascertain the association between a dependent variable and group of independent variables.

\subsection{Review Of Literature:}

Today's business is all about being green. From Wal-Mart to Apple, everyone is talking about how green their approach, packaging, or methods are. But green business is really in its infancy, and the future of being green will no doubt distill down to some very real and definable goals and practices. Various financial services adopted by green business are banks, credit card companies, insurance companies, consumer finance companies, stock brokerages and investment funds. Banking sector for great banking has its own significance. Green banking means promoting environmental friendly practices and reducing carbon footprint from banking activities. To aid the reduction of external carbon emission, bank should finance green technology and pollution reducing projects. The present paper aims to highlight Indian initiatives by various banks adopting green banking in India. Further, an attempt has been made to enlist certain strategies of adopting green banking.

\section{Green banking - The new strategic imperative:}

The paper's purpose is to highlight the green banking initiatives being taken by the Indian Banking Industry. Green banking involves promoting environmental and social responsibility by providing banking services in a new way befitting the new age of banking. Green banking is also called as Ethical banking that starts with the aim of protecting the environment. Ethical banks consider all the factors before considering a loan - whether the project is environment friendly or not. A company is awarded loan only when all the environment safety standards are followed. India is growing at a very fast rate and this development is mainly supported by the industrial sector. However the country faces a major challenge of controlling the impact of their business on the environment. For these industries, the banking sector is the major source of finance. Hence the role of the banks in controlling the environmental damage is extremely important. Banks are beginning to recognize that they have a social responsibility to fulfil as they emerge from the shadow of traditional banking. As per relatively indirect nature of their environmental and social impacts, banks need to examine the effects of 
their lending and investment decisions. Incorporating environmental and social criteria into business decisionmaking can reduce the adverse impacts of operating activities Financial institutions can do a lot to assist efforts for corporate social responsibility and achieve sustainability.

\section{Green banking Practices:}

Society is facing most complicated issues of climate change. People nowadays are more conversant with global warming and its inherent consequences on human life. So change is the need of the hour for the survival and continuous efforts should be made for the environmental management in a sustainable manner. It is not only the concern of the government and the direct polluters but also of other stakeholders like financial institutions such as banks, which are playing a fundamental role in the development of the society. Banking activities are not physically related to the environment, but the external impact of their customer activities is substantial. So there is need for banks to adopt green strategies into their operations, buildings, investments and financing strategies. The purpose of this paper is to highlight the rating standards given by RBI, the World Bank's environmental and social norms, the initiatives taken by public and private sector banks in India in the adopting practices and to enlist the significant strategies for adoption Banking.

\section{Environmental Sustainability through Banking: A Study on Private and Public Sector Banks in India}

Industrialization around the globe has triggered the pursuit of ever increasing needs and demands of the population and it has become symbolic of prosperity and development of an economy. But on the other hand it has resulted in the exploitation of the natural environment which in turn has disturbed the ecological balance. The disturbance in ecological balance has adversely impacted the human and its surrounding environment. The recent industrial disasters and natural disaster occur in the last three decades were directly or indirectly linked with the uneven industrialization. This in turn has raised an important issue of environmental protection among environmentalists, government and organization from all over the world. Environmental sustainability and sustainable development have become the important agenda in the international community. Various conferences and programs such as Earth Summit and United Nation Environmental program were being organized to create awareness about this alarming issue. Understanding the importance of the existence of human health \&well being governments as well as the organizations started taking various initiatives for the concern of environmental protection and sustainability. Environmental sustainability plays a vital role in sustainable growth and development, as the integration of social, economical and environmental sustainability help to make the development sustainable. Environmental protection has become a part of strategy in most organizations in the developed countries and started offering environment friendly or green products and services to the consumers. Learning from their western counterparts, the Indian organizations have also adopted environmental friendly practices within the organization. But the concept of environmental sustainability and green products and services is new to developing country like India.

\section{KomalSinghal}

\section{Green Banking: An Overview}

Global Warming \& Climate change are the main two discussed issues worldwide. These issues are caused mainly by human activities like burning fossil fuels for heat $\&$ energy, cleaning forest, fertilizing crops, storing waste in landfills, raising livestock and producing some kinds of industrial products which adversely impact our health, environment and economy. Hence some measures need to be taken urgently to save the environment from these issues. Being a financial organization of the country which is responsible for financing the economic and developmental activities of the country, banks have to address these above issues, both in terms of its obligations \& opportunities by virtue as a responsible corporate citizen \& as a financier. In this paper we tried to find out the ways in which banks can 'Go Greener ' and some of the green banking initiatives taken by the banks in India.

New Direction Line of Sustainable Development and Marketing in green banking Since the industrial revolution and the appearance of overproduction, degradation of environment has been oversized. Companies and also societies have not care about the negative effects on environment and nature; they have focused only on generating profit and revenue. Nowadays, they have to recognize that the carrying capacity of our Planet is finite, therefore they should not overuse nature. In the last decade, a lot of publications came to light, dealing with the social and environmental responsibility of firms. Contrarily, environmental awareness had developed more slowly in banks and financial institutions than in the manufacturing sector, because these institutions generally consider themselves to be a relative environmentally friendly industry. The goal of this paper is to identify the role of financial institutions in achieving sustainable development. The authors also attempt to show, why and how can this sector become the promoter of sustainability. 


\section{Green Banking Prospects In Bangladesh}

Green banking is the operation of the banking activities giving especial attention upon the social, ecological and environmental factors aiming at the conservation of nature and natural resources. Banks can be green through bringing changes in six main spheres of banks' activities - Change in Investment Management, Change in Deposit Management, Change in House Keeping, Change in the Process of Recruitment and Development of Human Capital, Corporate Social Responsibility (CSR), and Making Consciousness Among Clients and General Mass. Such an initiation can ensure a safe residence for upcoming generation. Bangladesh Bank has already issued circulars regarding this. Banks have already been asked to make their own green banking policy. Now we only need raising voice, keeping hand over hands, thinking in positive way and working in collective manner to make this a true.In this ECO-Conscious and Environmental friendly society the "Go Green" mantra permeates all spheres of life the banking sector too has adopted practices to reduce its carbon footprint. These initiatives range from banking operations to investments in companies involved in renewable and green technologies there is a tidal wave of change as more banks align their investment decisionmaking with the triple bottom line: people, planet, profit. All major transactions, including withdrawals, deposits and remittances up to Rs 40,000, will be made through green-channels. Green Banking is like a normal bank, which considers all the social and environmental factors; it is also called as an ethical bank. Ethical banks have started with the aim of protecting the environment. These banks are like a normal bank which aims to protect the environment and it is controlled by same authorities as what a traditional bank do. Green banking is like a normal bank, which considers all the social and environmental/ecological factors with an aim to protect the environment and conserve natural resources. It is also called as an ethical bank or a sustainable bank. They are controlled by the same authorities but with an additional agenda toward taking care of the Earth's environment / habitats / resources. For banking professionals green banking involves the tenets of sustainability, ethical lending, conservation and energy efficiency.

There are many differences compared with normal banking, Green Banks give more weight to environmental factors, their aim is to provide good environmental and social business practice, they check all the factors before lending a loan, whether the project is environmental friendly and has any implications in the future, you will awarded a loan only when you follow all the environmental safety standards.

Defining green banking is relatively easy. Green Banking means promoting environmental - friendly practices and reducing your carbon footprint from your banking activities. This comes in many forms

Using online banking instead of branch banking.

Paying bills online instead of mailing them.

Opening up accounts at online banks, instead of large multi-branch banks

Green banking can benefit the environment either by reducing the carbon footprint of consumers or banks. Either a bank or a consumer can conserve paper and benefit the environment. Ideally, a green banking initiative will involve both. Online banking is an example of this. When a bank's customer goes online, the environmental benefits work both ways. Green banking means combining operational improvements and technology, and changing client habits.

\section{Steps in Green Banking}

From the empirical study, it is found that following are some of the steps that can be taken for going green in banking:

Go Online:- Online banking is the developing concept in young and corporate India. Online banking helps in additional conservation of energy and natural resources. Online Banking includes: a. Paying bills online, b. Remote deposit, c. Online fund transfers and d. Online statements. It creates savings from less paper, less energy, and less expenditure of natural resources from banking activities. Customers can save money be avoiding late payments of fees and save time by avoiding standing to queues and paying the bill from home online.

Use Green Checking Accounts:- Customers can check their accounts on ATM or special touch screens in the banks. This can be called as green checking of account. Using a green checking account helps the environment by utilizing more online banking services including online bill payment, debit cards, and online statements. Banks should promote green checking by giving some incentives to customers by giving higher rate of interests, waiver or discount in fees etc.

Use Green Loans for Home Improvements:- The Ministry of Non-renewable Resource in association with some nationalized and scheduled banks undertook an initiative to go green by paying low interest loans to the customers who would like to buy solar equipments. The rate of interest is as low as $4 \%$ p.a. Before you undertake a major home improvement project, study if the project can be done in an eco-friendly manner and if you might qualify for a green loan from a bank Green loan are perfect for energy-saving project around the 
house. The new Green Home Loan Scheme from SBI, for instance, will support environmentally friendly residential projects and offer various concessions. These loans will be sanctioned for projects rated by the Indian Green Building Council (IGBC) and offer several financial benefits -a 5 percent concession in margin, 0.25 percent concession in interest rate and processing fee waiver.

Power Savings Equipments:- Banks can directly contribute to controlling climate change and as an initial step they intend to start a campaign to replace all fused GSL bulbs, in all owned premises offices and residential. Banks can also make a feasibility study to make rain water harvesting mandatory in all the Bank's owned premises. In December 2009 Indusind Bank inaugurated Mumbai's first solar-powered ATM as part of its 'Green Office Project' campaign titled 'Hum aurHariyali'

Use Green Credit Cards:- Some of the banks introduced Green Credit Card. The benefit of using a green credit card is that banks will donate funds to an environment-friendly nonprofit organization from every rupee you spend on your credit card to a worthwhile cause of environment protection.

Save Paper:- Bank should purchase recycled paper products with the highest postconsumer waste content possible. This includes monthly statements, brochures, ATM receipts, annual reports, newsletters, copy paper, envelopes etc. Whenever available, vegetable-based inks are used instead of less environmentally friendly oilbased inks.

Use of Solar and Wind Energy:- Using solar and wind energy is one of the noble cause for going green. State Bank of India (SBI) has become the first bank in the country to venture into generation of green power by installing windmills for captive use. As part of its green banking initiative, SBI has installed 10 windmills with an aggregate capacity of $15 \mathrm{MW}$ in the states of Tamil Nadu, Maharashtra and Gujarat.

Mobile Banking:- Mobile banking is tricky. On the one hand, it is great to have the ability to check balances, transfer funds or pay bills from you phone. One the other hand, it saves time and energy of the customers. It also helps in reducing use of energy and paper of the bank. Most of the Indian banks introduced this paper-less facility. India is on a higher growth trajectory for last one and half decade and the industrial sector plays the most important role in India's growth story. However, Indian industry faces the challenges of controlling environmental impact of their business i.e. reducing pollution and emission of their clients. Though government has been trying to address the issue by framing environmental legislations and encouraging industry to follow environmental technologies and practices, they would not be enough given the poor track records of enforcement, public awareness and inability to derive competitive advantage by producing eco-friendly products. Incidentally, India's is the world's sixth largest and second fastest growing country in terms of producing green house gases. Delhi, Mumbai and Chennai are the three of the world's ten most polluted cities. The major polluting industries in India are (a) primary metallurgical industries namely zinc, copper, steel etc. (b) paper \& pulp (c) pesticides/insecticides (d) refines (e) fertilizers (f) tanneries (g) sugar (h) textiles (i) chemicals/pharmaceuticals etc. The banking operation and investment by financial institutions should take care of environmental management of these polluting industries by improving the overall environment, the quality and conversation of life, level of efficiency in using materials and energy, quality of services and products. In this context, the role of banking sector, which is on major financing sources to the Industries, assumes high importance. The environmental regulations in India can be broadly classified into two broad categories i.e. command and control regulations and liability law. The command and control regulations are ex ante regulations that are designed to dissuade environmentally damaging projects. This regulation is implemented by setting industry specific pollution standards, scrutinizing the projects and granting/denying permissions by the concerned authorities like Ministry of Environment and Forest. The liability laws are ex post in nature and are implemented by enforcing authorities through imposing fines, closing down the defaulting industries etc. However there is no law and rule in India that can hold banks responsible for scrutinizing investment projects before financing and for the environmental damage created by its client. Once legal framework for the environmental pollution standards are formulated in India, the polluting industries either have to close down or have to make necessary investment to comply with the standard. In this process these industries will loose their competitiveness in the international market, which would directly affect Indian economy and the banking sector.

\section{Analysis Relating To Objective-I}

\subsection{Statistical Analysis Of Demographic Factors And Variables Taken Up For The Study}

This chapter intends to statistically analyse the data collected using statistical tools and draw inferences thereof. The analysis highlights the awareness, green banking facilities awareness and difficulties faced by respondents while using green banking. 


\section{Variables Taken Up For The Study:}

The following are the various variables taken up for the purpose of this study. These variables were tested along with the demographic factors, in order to satisfy the objectives of the study.

- Awareness among respondents

- Green banking facilities

- Difficulties faced

\section{Demographic factors of the Respondent and Awareness of green banking}

H0: There is no association difference between Age and Awareness of green banking

H1: There is association difference between Age and Awareness of green banking.

Table :3.1.1 Chi-Square for Age and Awareness of green banking

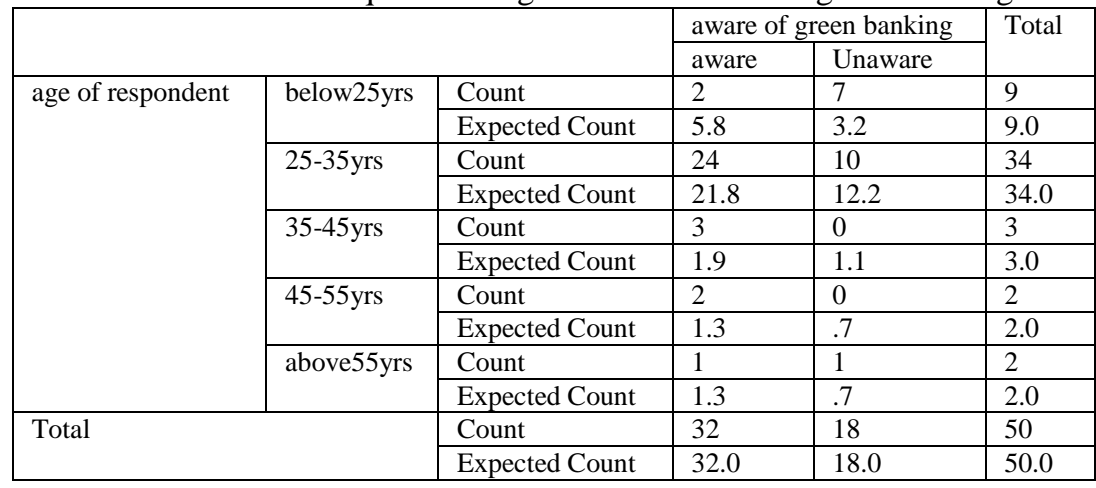

\begin{tabular}{|l|l|l|l|}
\hline Chi-Square Tests & Value & Df & Asymp. Sig. (2-sided) \\
\hline Pearson Chi-Square & $10.441^{\mathrm{a}}$ & 4 & .034 \\
\hline Likelihood Ratio & 11.840 & 4 & .019 \\
\hline Linear-by-Linear Association & 3.341 & 1 & .068 \\
\hline N of Valid Cases & 50 & & \\
\hline \multicolumn{4}{|l|}{} \\
\hline
\end{tabular}

Interpretation: The above table clearly shows that Age has major role to be played with respect to awareness of concept of green banking. The Asymp.value of 0.34 is lesser than the Critical value of 0.05 , Rejecting the H0.There is an association between age and awareness of green banking. Age group with 25-35 are more aware then the other age grou

TABLE: 3.1.2 Chi Square Income And Awareness Of Green Banking H0: There is no association between Income and Awareness of green banking.

H1: There is association between Income and Awareness of green banking.

\begin{tabular}{|c|c|c|c|c|c|}
\hline & \multicolumn{2}{|c|}{ Aware of green banking } & \multirow[t]{2}{*}{ Total } \\
\hline & & & Aware & Unaware & \\
\hline \multirow[t]{8}{*}{ Income } & \multirow[t]{2}{*}{ below $25 \mathrm{k}$} & Count & 1 & 8 & 9 \\
\hline & & Expected Count & 5.8 & 3.2 & 9.0 \\
\hline & \multirow[t]{2}{*}{$25 \mathrm{k}-50 \mathrm{k}$} & Count & 7 & 6 & 13 \\
\hline & & Expected Count & 8.3 & 4.7 & 13.0 \\
\hline & \multirow[t]{2}{*}{$50 \mathrm{k}-11 \mathrm{lac}$} & Count & 18 & 2 & 20 \\
\hline & & Expected Count & 12.8 & 7.2 & 20.0 \\
\hline & \multirow[t]{2}{*}{ above1lac } & Count & 6 & 2 & 8 \\
\hline & & Expected Count & 5.1 & 2.9 & 8.0 \\
\hline \multirow{2}{*}{\multicolumn{2}{|c|}{ Total }} & Count & 32 & 18 & 50 \\
\hline & & Expected Count & 32.0 & 18.0 & 50.0 \\
\hline
\end{tabular}

\begin{tabular}{|l|l|l|l|}
\hline Chi-Square Tests & Value & Df & $\begin{array}{l}\text { Asymp. Sig. } \\
(2 \text {-sided) }\end{array}$ \\
\hline Pearson Chi-Square & $17.797^{\text {a }}$ & 3 & .000 \\
\hline Likelihood Ratio & 19.117 & 3 & .000 \\
\hline Linear-by-Linear Association & 12.586 & 1 & .000 \\
\hline N of Valid Cases & 50 & & \\
\hline
\end{tabular}


InterpretatioN: Income has got greater role to play with respect to awareness which is very clear from the table. The Asym.value is 0.00 which is lower than the Critical value 0.05 rejecting the null hypothesis. There is association between Income and Awareness. Respondents with Income less than 25000 are not aware of green banking

Figure 3.1.2.1

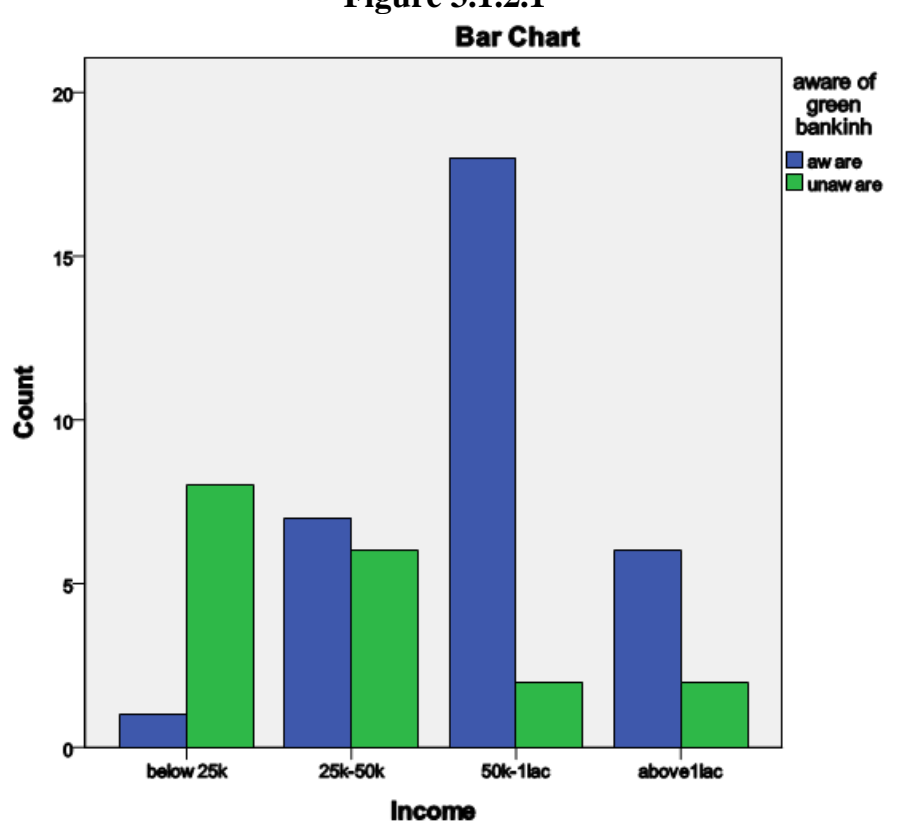

TABLE: 3.1.3 Chi Square Educational Qualification And Awareness Of Green Banking H0: There is no association between Educational Qualification and Awareness of green banking. H1: There is association between Educational Qualification and Awareness of green banking.

\begin{tabular}{|c|c|c|c|c|}
\hline \multicolumn{5}{|c|}{ Educational qualification * Aware of green banking Cross tabulation } \\
\hline \multicolumn{5}{|l|}{ Count } \\
\hline & & \multicolumn{2}{|c|}{$\begin{array}{l}\begin{array}{l}\text { Aware of green } \\
\text { banking }\end{array} \\
\end{array}$} & \multirow[t]{2}{*}{ Total } \\
\hline & & Aware & Unaware & \\
\hline \multirow[t]{3}{*}{ Educational qualification } & Under graduate & 2 & 9 & 11 \\
\hline & Post graduate & 23 & 7 & 30 \\
\hline & Professional & 7 & 2 & 9 \\
\hline \multicolumn{2}{|l|}{ Total } & 32 & 18 & 50 \\
\hline
\end{tabular}

\begin{tabular}{|l|l|l|l|}
\hline Chi-Square Tests & Value & Df & Asymp. Sig. (2-sided) \\
\hline Pearson Chi-Square & $12.853^{\mathrm{a}}$ & 2 & .002 \\
\hline Likelihood Ratio & 12.780 & 2 & .002 \\
\hline Linear-by-Linear Association & 8.421 & 1 & .004 \\
\hline N of Valid Cases & 50 & & \\
\hline
\end{tabular}

Interpretation: Educational Qualification has got a major role to play is evidently clear from the table. The calculated $\mathrm{p}$-value is less than the critical value .05 therefore rejecting the null hypothesis. There is an association between educational qualification and awareness of green banking 


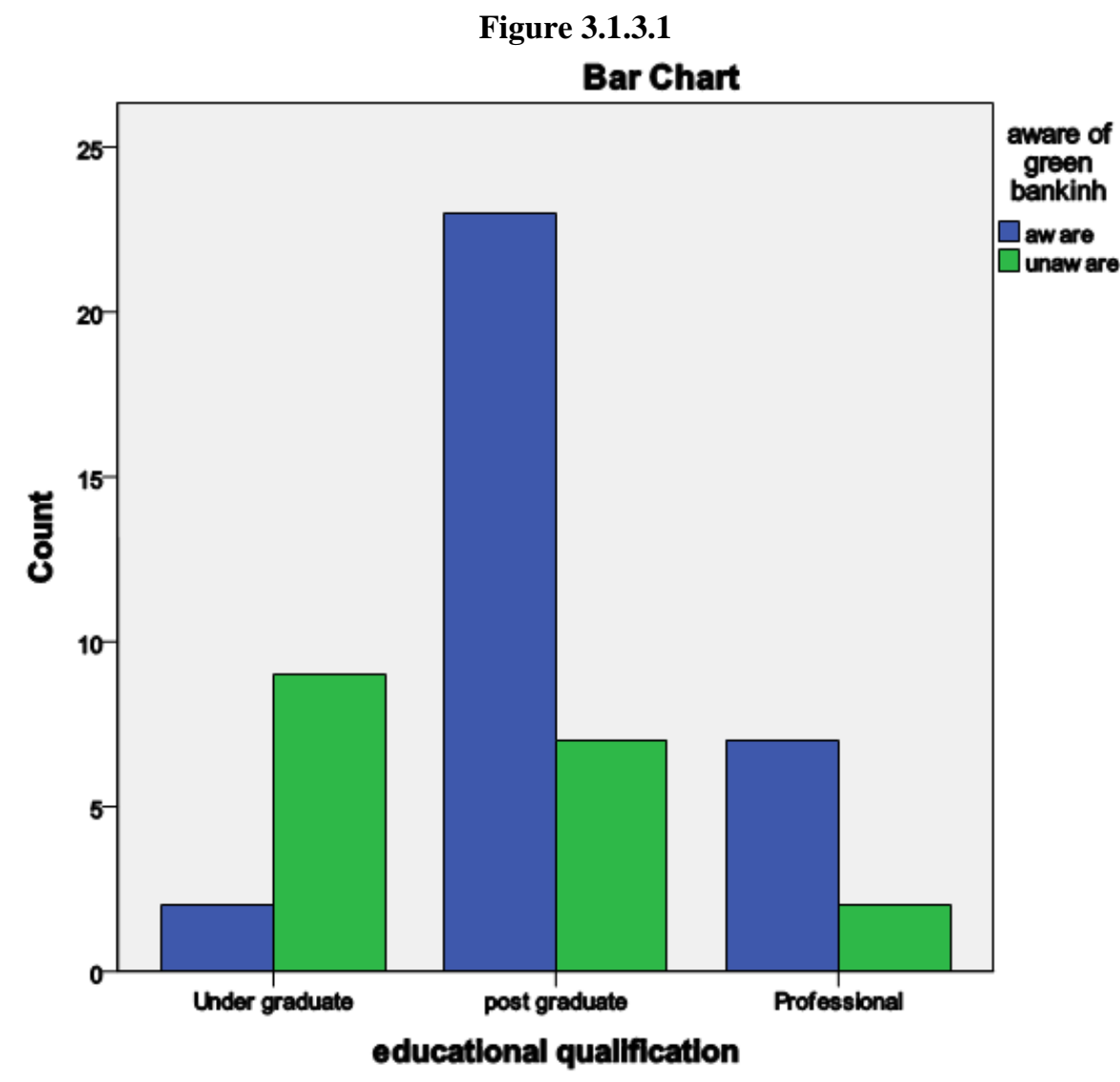

\section{2analysis Relating To Objective-Ii Percentage Analysis Tables For Different Green Banking Facilities}

TABLE: 3.2.1

\begin{tabular}{|l|l|l|l|l|l|}
\hline \multicolumn{6}{|l|}{ Environmental friendly and ethical policies } \\
\hline & Frequency & Percent & Valid Percent & $\begin{array}{l}\text { Cumulative } \\
\text { Percent }\end{array}$ \\
\hline Valid & Agree & 49 & 98.0 & 100.0 & 100.0 \\
\hline Missing & System & 1 & 2.0 & & \\
\hline Total & 50 & 100.0 & & \\
\hline
\end{tabular}

Interpretation: All most all respondents are aware about their banks environmentally friendly policies , ethical policies and how much they are committed towards green.

TABLE: 3.2.2

\begin{tabular}{|l|l|l|l|l|l|}
\hline \multicolumn{2}{|l|}{ Cheques on recycled paper } & Frequency & Percent & Valid Percent & $\begin{array}{l}\text { Cumulative } \\
\text { Percent }\end{array}$ \\
\hline \multirow{2}{*}{ Valid } & Aware & 16 & 32.0 & 32.0 & 32.0 \\
\cline { 2 - 6 } & Unaware & 34 & 68.0 & 68.0 & 100.0 \\
\cline { 2 - 6 } & Total & 50 & 100.0 & 100.0 & \\
\hline
\end{tabular}

Interpretation: Majority of the respondents are quite unaware that the cheques are printed on recycled paper. Only $32 \%$ are aware that cheques are printed on recycled paper.

TABLE: 3.2 .3

\begin{tabular}{|l|l|l|l|l|l|}
\hline \multicolumn{2}{|l|}{ Online bank accounts maintenance } \\
\hline \multirow{2}{*}{} & Frequency & Percent & Valid Percent & $\begin{array}{l}\text { Cumulative } \\
\text { Percent }\end{array}$ \\
\hline \multirow{3}{*}{ Valid } & Aware & 48 & 96.0 & 96.0 & 96.0 \\
\cline { 2 - 6 } & Unaware & 2 & 4.0 & 4.0 & 100.0 \\
\cline { 2 - 6 } & Total & 50 & 100.0 & 100.0 & \\
\hline
\end{tabular}


Interpretation: All respondents are aware about online bank accounts are maintenance. It's very clear that all respondents do their transactions online and do maintain their accounts online

TABLE: 3.2.4

\begin{tabular}{|l|l|l|l|l|l|}
\hline \multicolumn{2}{|l|}{ Automatic cheque deposit } & Frequency & Percent & Valid Percent & $\begin{array}{l}\text { Cumulative } \\
\text { Percent }\end{array}$ \\
\hline \multirow{2}{*}{ Valid } & Aware & 31 & & & 63.3 \\
\cline { 2 - 7 } & Unaware & 18 & 62.0 & 63.3 & 100.0 \\
\cline { 2 - 6 } & Total & 49 & 36.0 & 36.7 & \\
\hline Missing & System & 1 & 98.0 & 100.0 & \\
\hline Total & 50 & 100.0 & & \\
\hline
\end{tabular}

Interpretation: 62\% of the respondents are aware about cheque deposit adopted in their respective banks, $36 \%$ of the respondents are unaware of the automatic cheque deposit system existing in their banks.

TABLE: 3.2.5

\begin{tabular}{|c|c|c|c|c|c|}
\hline \multicolumn{6}{|c|}{ Green mortgage } \\
\hline & & Frequency & Percent & Valid Percent & $\begin{array}{l}\text { Cumulative } \\
\text { Percent }\end{array}$ \\
\hline \multirow[t]{3}{*}{ Valid } & Aware & 9 & 18.0 & 18.8 & 18.8 \\
\hline & Unaware & 39 & 78.0 & 81.3 & 100.0 \\
\hline & Total & 48 & 96.0 & 100.0 & \\
\hline Missing & System & 2 & 4.0 & & \\
\hline \multicolumn{2}{|l|}{ Total } & 50 & 100.0 & & \\
\hline
\end{tabular}

Interpretation: Respondents are quite unaware about green mortgage existing in their banks, only $18 \%$ are aware about green mortgage

Figure. 3.2.5.1

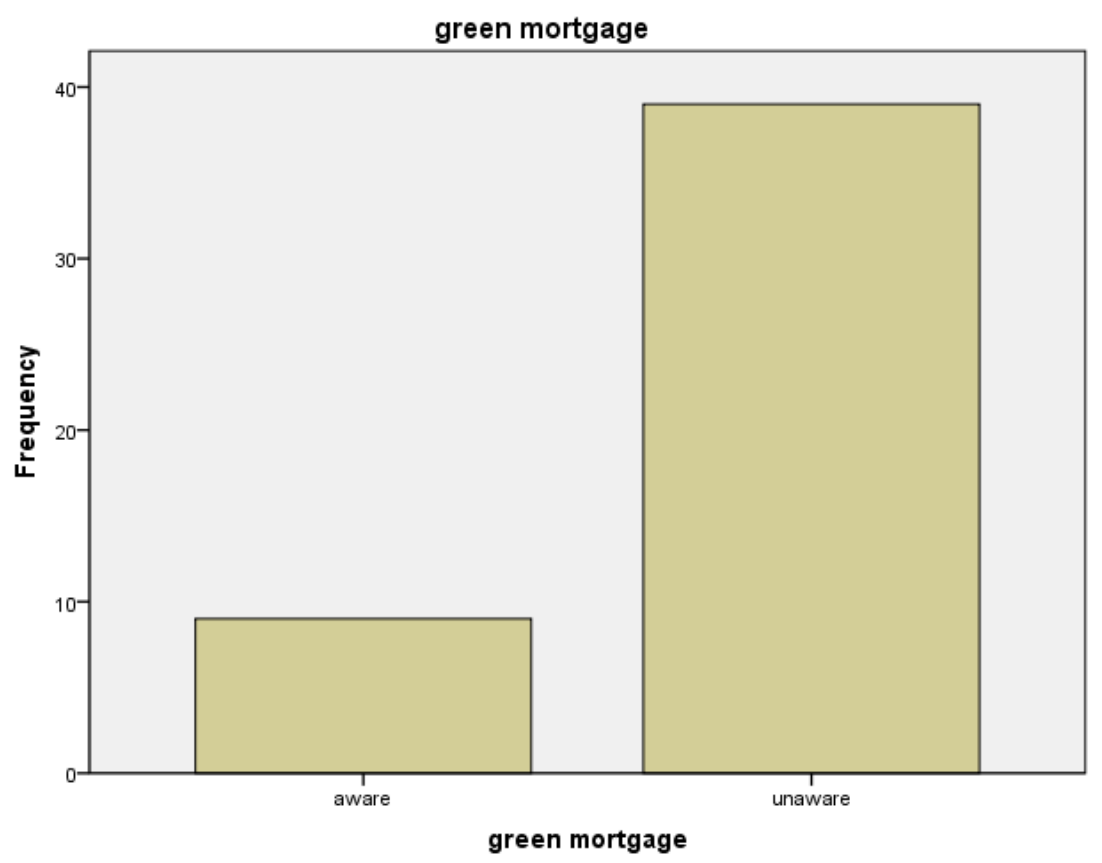

TABLE 3.2.6

\begin{tabular}{|l|l|l|l|l|l|}
\hline \multicolumn{2}{|l|}{ Percentage of loans awarded to environmentally focussed companies } \\
\hline \multirow{2}{*}{} & Frequency & Percent & Valid Percent & $\begin{array}{l}\text { Cumulative } \\
\text { Percent }\end{array}$ \\
\hline \multirow{3}{*}{ Valid } & Aware & 8 & 16.0 & 16.3 & 16.3 \\
\cline { 2 - 6 } & Unaware & 41 & 82.0 & 83.7 & 100.0 \\
\cline { 2 - 6 } & Total & 49 & 98.0 & 100.0 & \\
\hline Missing & System & 1 & 2.0 & & \\
\hline Total & 50 & 100.0 & & \\
\hline
\end{tabular}


Interpretation: Respondents are unaware of that percentages of loans are awarded to environmentally focussed companies. Only few respondents are aware about such type of loans offered by their banks.

TABLE: 3.2.7

\begin{tabular}{|l|l|l|l|l|l|}
\hline \multicolumn{2}{|l|}{ Energy saving efforts or environmental improvements } \\
\hline \multirow{2}{*}{} & Frequency & Percent & Valid Percent & $\begin{array}{l}\text { Cumulative } \\
\text { Percent }\end{array}$ \\
\hline \multirow{3}{*}{ Valid } & Aware & 26 & 52.0 & 52.0 & 52.0 \\
\cline { 2 - 6 } & Unaware & 24 & 48.0 & 48.0 & 100.0 \\
\cline { 2 - 6 } & Total & 50 & 100.0 & 100.0 & \\
\hline
\end{tabular}

Interpretation: Respondents are aware about the energy saving efforts taken by the banks in their respective buildings, respondents are also unaware about the energy saving efforts adopted.

TABLE: 3.2.8

\begin{tabular}{|l|l|l|l|l|l|}
\hline \multicolumn{2}{|l|}{ Use of solar powered ATM } \\
\hline \multirow{2}{*}{} & Frequency & Percent & Valid Percent & $\begin{array}{l}\text { Cumulative } \\
\text { Percent }\end{array}$ \\
\hline \multirow{3}{*}{ Valid } & Aware & 16 & 32.0 & 32.0 & 32.0 \\
\cline { 2 - 6 } & Unaware & 34 & 68.0 & 68.0 & 100.0 \\
\cline { 2 - 6 } & Total & 50 & 100.0 & 100.0 & \\
\hline
\end{tabular}

Interpretation: Respondents are unaware about the use of solar powered ATM being installed, only $32 \%$ are aware about the use of solar powered ATM.

TABLE 3.2.9

\begin{tabular}{|l|l|l|l|l|l|}
\hline \multicolumn{2}{|l|}{ E-Investment services } & Frequency & Percent & Valid Percent & $\begin{array}{l}\text { Cumulative } \\
\text { Percent }\end{array}$ \\
\hline \multirow{2}{*}{ Valid } & Aware & 34 & 68.0 & 69.4 & 69.4 \\
\cline { 2 - 6 } & Unaware & 15 & 30.0 & 30.6 & 100.0 \\
\cline { 2 - 6 } & Total & 49 & 98.0 & 100.0 & \\
\hline Missing & System & 1 & 2.0 & & \\
\hline Total & 50 & 100.0 & & \\
\hline
\end{tabular}

Interpretation: Respondents are aware about E-Investment services while30\%are unaware about the EInvestment services.

TABLE: 3.2.10

\begin{tabular}{|l|l|l|l|l|l|}
\hline \multicolumn{6}{|l|}{ Invest in mutual funds engaged in Solar or Wind energy } \\
\hline \multicolumn{2}{|c|}{} & Frequency & Percent & Valid Percent & $\begin{array}{l}\text { Cumulative } \\
\text { Percent }\end{array}$ \\
\hline \multirow{3}{*}{ Valid } & Aware & 12 & 24.0 & 24.0 & 24.0 \\
\cline { 2 - 6 } & Unaware & 37 & 74.0 & 74.0 & 98.0 \\
\cline { 2 - 6 } & 99.00 & 1 & 2.0 & 2.0 & 100.0 \\
\cline { 2 - 6 } & Total & 50 & 100.0 & 100.0 & \\
\hline
\end{tabular}

Interpretation: Respondents are unaware about the investing in mutual funds engaged in solar or wind energy. Only $24 \%$ are aware about the investing in mutual funds engaged in solar or wind energy.

TABLE: 3.2.11

\begin{tabular}{|c|c|c|c|c|c|}
\hline \multicolumn{6}{|c|}{ Green credit cards } \\
\hline & & Frequency & Percent & Valid Percent & $\begin{array}{l}\text { Cumulative } \\
\text { Percent }\end{array}$ \\
\hline \multirow[t]{3}{*}{ Valid } & Aware & 7 & 14.0 & 14.0 & 14.0 \\
\hline & unaware & 43 & 86.0 & 86.0 & 100.0 \\
\hline & Total & 50 & 100.0 & 100.0 & \\
\hline
\end{tabular}

Interpretation: Majority of respondents are unaware of green credit cards service offered by their banks. Only 14\%are aware about the green credit card service offered.

TABLE: 3.2.12

\begin{tabular}{|l|l|l|l|l|l|}
\hline \multicolumn{2}{|l|}{ Recycled debit and credit } \\
\multicolumn{2}{|l|}{} & Frequency & Percent & Valid Percent & $\begin{array}{l}\text { Cumulative } \\
\text { Percent }\end{array}$ \\
\hline \multirow{2}{*}{ Valid } & Aware & 18 & 36.0 & 36.7 & 36.7 \\
\cline { 2 - 6 } & Unaware & 31 & 62.0 & 63.3 & 100.0 \\
\hline
\end{tabular}




\begin{tabular}{|l|l|l|l|l|l|}
\hline & Total & 49 & 98.0 & 100.0 & \\
\hline Missing & System & 1 & 2.0 & & \\
\hline Total & 50 & 100.0 & & \\
\hline
\end{tabular}

Interpretation: $62 \%$ of the respondents are unaware that the debit and credit cards are recycled for environmental cause, $36 \%$ are aware that the debit and credit cards recycled.

TABLE: 3.2.13

\begin{tabular}{|l|l|l|l|l|l|}
\hline \multicolumn{2}{|l|}{ Mobile banking to check balance } \\
\hline & Frequency & Percent & Valid Percent & $\begin{array}{l}\text { Cumulative } \\
\text { Percent }\end{array}$ \\
\hline Valid & Aware & 49 & 98.0 & 100.0 & 100.0 \\
\hline Missing & System & 1 & 2.0 & & \\
\hline Total & 50 & 100.0 & & \\
\hline
\end{tabular}

Interpretation: All the respondents are aware about mobile banking, transfer funds abs paying bills through phones, with the latest technology up gradation in mobile phones all the respondents are comfortable and confident in using the mobile banking

\section{Problems Faced By Respondents}

TABLE: 3.2.14 Problems faced while using

\begin{tabular}{|l|l|l|l|l|l|}
\hline \multicolumn{2}{|c|}{} & Frequency & Percent & Valid Percent & $\begin{array}{l}\text { Cumulative } \\
\text { Percent }\end{array}$ \\
\hline \multirow{5}{*}{ Valid } & Fear of security breach & 17 & 34.0 & 35.4 & 35.4 \\
\cline { 2 - 6 } & Privacy & 10 & 20.0 & 20.8 & 56.3 \\
\cline { 2 - 6 } & Lack of facility & 17 & 34.0 & 35.4 & 91.7 \\
\cline { 2 - 6 } & None & 4 & 8.0 & 8.3 & 100.0 \\
\cline { 2 - 6 } & Total & 48 & 96.0 & 100.0 & \\
\hline Missing & System & 2 & 4.0 & & \\
\hline Total & 50 & 100.0 & & \\
\hline
\end{tabular}

Interpretation: Respondents are afraid to use the facility offered by the banks for the fear of security, and breach of security. $34 \%$ of them feel lack of facility is the major drawback for not using it.

TABLE: 3.2.15

\begin{tabular}{|l|l|l|l|l|l|}
\hline \multicolumn{2}{|l|}{ Bank you access frequently } & Frequency & Percent & Valid Percent & $\begin{array}{l}\text { Cumulative } \\
\text { Percent }\end{array}$ \\
\hline \multirow{2}{*}{} & & & & 24.0 \\
\hline \multirow{6}{*}{ Valid } & SBI & 12 & 24.0 & 24.0 & 54.0 \\
\cline { 2 - 6 } & ICICI Bank & 15 & 30.0 & 30.0 & 64.0 \\
\cline { 2 - 6 } & HDFC bank & 5 & 10.0 & 10.0 & 78.0 \\
\cline { 2 - 6 } & Axis bank & 7 & 14.0 & 14.0 & 80.0 \\
\cline { 2 - 6 } & Indian bank & 1 & 2.0 & 2.0 & 94.0 \\
\cline { 2 - 6 } & Canara bank & 7 & 14.0 & 14.0 & 96.0 \\
\cline { 2 - 6 } & ICICI\&canara & 1 & 2.0 & 2.0 & 100.0 \\
\cline { 2 - 6 } & SBI\&canara & 2 & 4.0 & 4.0 & \\
\cline { 2 - 6 } & Total & 50 & 100.0 & 100.0 & \\
\hline
\end{tabular}

Interpretation: Respondents feel comfortable using ICICI Bank and SBI bank when considered other banks while using green banking facility. Lack of security and Lack of facility are the problems faced by the majority of respondents.

Table: 3.2.16

\begin{tabular}{|l|l|l|l|l|l|}
\hline \multicolumn{2}{|c|}{ Aware of green banking } \\
\hline \multirow{2}{*}{} & Frequency & Percent & Valid Percent & $\begin{array}{l}\text { Cumulative } \\
\text { Percent }\end{array}$ \\
\hline \multirow{3}{*}{ Valid } & aware & 32 & 64.0 & 64.0 & 64.0 \\
\cline { 2 - 6 } & unaware & 18 & 36.0 & 36.0 & 100.0 \\
\cline { 2 - 6 } & Total & 50 & 100.0 & 100.0 & \\
\hline
\end{tabular}

INTERPRETATION: $64 \%$ of the respondents are aware of concept of green banking While $36 \%$ of the respondents are unaware of concept of green banking. 


\section{One-Wayanova}

H0: There is no significant association between facilities of green banking and problems faced while using the facility.

H1:There is significant association between facilities of green banking and problems faced while using the facility.

Table: 3.2.17

\begin{tabular}{|l|l|l|l|l|l|}
\hline ANOVA & Sum of Squares & Df & Mean Square & F & Sig. \\
\hline Between Groups & 9.570 & 3 & 3.190 & .542 & .656 \\
\hline Within Groups & 235.430 & 40 & 5.886 & & \\
\hline Total & 245.000 & 43 & & & \\
\hline
\end{tabular}

Interpretation: Aggregate of facilities and problems faced by the respondents are analysed to examine, that the Asmyvalue is 0.656 greater than Critical Value of 0.05 AcceptingH0. There is no significant difference or association with facilities and problems faced in using green banking.

\subsection{Summary Of Findings}

\section{Summary of Findings And Conclusion}

- Chi-square analysis clearly states that respondents with age group 25-35 are using all the facilities in the concept of green banking.

- Chi-square states that qualification plays an vital role in using green banking, post graduates use major facilities than others.

- One way ANOVA gives out clear picture that facilities of green banking has no association with problems faced.

- $64 \%$ of the respondents are aware of green banking and $36 \%$ of them are unaware of green banking.

- $98 \%$ are aware of the meaning of green banking,

- $32 \%$ of the respondents are aware of cheques on recycled paper, $68 \%$ are unaware of cheques on recycled paper.

- $96 \%$ of the respondents are aware of online banking and accounts maintenance while only $4 \%$ are unaware.

- $62 \%$ are aware of Automatic cheque deposit services offered, $36 \%$ are unaware of the service offered.

- $78 \%$ of the respondents are unaware of automatic cash deposit while $18 \%$ are only aware of automatic cash deposit.

- $18 \%$ respondents are aware of green mortgage while majority are unaware of green mortgage.

- $16 \%$ of the respondents are aware of percentage of loans awarded to environmentally focussed companies and $82 \%$ are unaware of percentage of loans awarded to environmentally focussed companies.

- $32 \%$ of the respondents are aware of use solar powered ATM machines while $68 \%$ are unaware of solar powered ATM.

- Majority of respondents are unaware of green credit cards service offered by their banks. Only $14 \%$ are aware about the green credit card service offered.

- Respondents are unaware about the investing in mutual funds engaged in solar or wind energy. Only $24 \%$ are aware about the investing in mutual funds engaged in solar or wind energy.

- 30\%Respondents feel comfortable using ICICI Bank and 24\%SBI bank when considered other banks while using green banking facility.14\% of respondents using Canara bank and Axis bank.10\%use HDFC bank.

- $\quad 34 \%$ respondents feel Lack of security and Lack of facility are the problems faced by the majority of respondents.20\% fear for breach of privacy.

- $98 \%$ of the respondents use mobile banking.

- $36 \%$ of the respondents are aware of recycled debit and credit cards while others are unaware.

\section{Conclusion}

Banks are the only industry which is considered as non polluting industry, but due to environmental and climatic change banks need to change and adapt to environmental friendly practices.Green Banking means promoting environmental - friendly practices and reducing your carbon footprint from your banking activities. Green banking concept is pretty well known by many customers with facilities relating to Online banking transactions and mobile banking. Customers are not aware of many green banking products and services like recycled debit and credit cards, automatic cash and cheque deposit, percentage of loans for environmental based companies and individuals, green credit cards, solar powered ATM's.Banks should take all necessary steps to educate the customers about the green products and services; it is the responsibility of every bank to do it. 
It is the responsibility of bank to protect the environment, as they are the financial intermediaries and channel for the future economic growth

Banks can make their building green building and make it evidently clear even to trespassers about the concept of green banking. Certificate of green building should be made mandatory by RBI of India.

The study conducted here is limited but not exhaustive, there is scope for future research about green banking. The researchers can explore and make further study about green building, green data centre and other facilities of green banking.

\section{Recommendations}

- Awareness of green banking is more with age group 25-35years; banks can take measures for spreading the awareness about green banking to senior citizens.

- Steps can be taken by banks to educate them about the easy accessibility of green banking products and services.

- Periodic campaigns have to be made mandatory by the banks to educate people about the green banking services.

- Banks can have green lounge in all the retail branches, so people walking in to the branch will be aware of green banking products and services.

- Banks can have E-Lounge to entertain customers to freely access their account, who face the problem of lack of facility and lack of security.

- Bank employees should help their customers in educating them about the paperless transactions.

- Banks can avoid tokens in paper instead they can allot numbers through Mobile phones.

- Automatic cheque and Automatic cash deposit can be made without paper receipt; immediate SMS alert can be made instead of the receipt.

- Banks can place certificate obtained from government stating that the entire building is green. With green IT, greening buildings and green data centre.

\section{Bibliography}

[1]. The lists of different articles are taken from journals, articles and research papers:

[2]. A study of green banking trends in India-Dr.Nishikant Jha and Shraddha Bhome

[3]. Ankit Goel , K.R. Mangalam, Green banking practices, International Journal of Research in Business Management , Vol.2, Issue 4, April 2014, 45-62

[4]. Bihari and Suresh Chandra Banking for environmental management, International Journal of Business Insights and Transformation, Oct 2010-Mar2011, Vol.4 Issue, Pg. 82-87

[5]. Dr.BahlSarita, Associate professor P.G. Department of Commerce and Management, The new strategic imperative, online published on $13^{\text {th }}$ February 2012.

[6]. Kanak Tara, Saumya Singh Department of Management studies, Indian school of Mines, Dhanbad-826004, Jharkhand, Banking for Environmental Management: A Paradigm Shift.

[7]. Md. Mustafizur Rahman, Green banking -A study on private banks verses public banks, Asian Business Review, Volume 2, No.2/2013 (Issue 4)

[8]. The list of websites visited are:

[9]. www.googlescholar.com

[10]. Www.ssrn.com

[11]. www.ibrdt.com

[12]. www.rbi.com 